\title{
Analisis Diksi Dan Majas Dalam Novel Kami Bukan Sarjana Kertas Karya J.S Khairen Tinjauan Stilistika dan Implementasi Sebagai Bahan Ajar Pada SMP
}

\author{
Christin Agustina Purba ${ }^{1}$, Meita Sitanggang ${ }^{2}$, Agrita Sari $^{3}$, Betris Maluma Br Manik ${ }^{4}$ \\ E-mail: christinpurba@unprimdn.ac.id ${ }^{1}$, meitasitanggang98@gmail.com², \\ agritasari99@gmail.com ${ }^{3}$, betrismalumma27@gmail.com ${ }^{4}$ \\ Universitas Prima Indonesia
}

\begin{abstract}
Abstrak
Penelitian ini menggunakan metode analisis kualitatif deskriptif dan penelitian ditemukan dengan kajian stilistika. Hasil penelitian dalam novel ini ditemukan berbagai kata khiasan dan majas yang menambah perbendaharaan penggunaan kata-kata khiasan yang menceritakan kisah perjuangan seorang anak mahasiswa yang mempunyai banyak masalah dalam kehidupannya dan dapat menjadi inspirasi bagi siswa sekolah menengah pertama. Adapun unsur diksi dan majas didalam novel tersebut akan menambah wawasan bagi setiap pembaca dan juga dapat diterapkan didalam pembelajaran siswa sekolah menengah pertama. Di dalam diksi memilki kata pilihan yang menyampaikan gagasan atau cerita di dalam novel yang jarang didengar oleh setiap pembaca dan dapat menambah pengetahuan kata-kata baru yang mungkin jarang didengar oleh pembaca sebelumnya.Dalam peneleitian ini fungsi majas didalam novel dapat menarik pembaca dan menciptakan rasa keinginan membaca dalam novel karena banyak kata-kata yang sangat menarik dan menimbulkan keinginan untuk membaca
\end{abstract}

Kata kunci: diksi, majas, stikistika, novel.

\section{PENDAHULUAN}

Didalam kehidupan kita sehari-hari tidak akan pernah hilang dengan adanya suatu bahasa baik itu secara lisan maupun tulisan. Dalam bahasa Indonesia ada terdapat tiga bagian besar yaitu penggunaa ejaan, diksi, penyusunan kalimat. Didalam penelitian ini yang akan dibahas yaitu 
penggunaan diksi dan gaya bahasa yang terdapat dalam novel Kami Bukan Sarjana Kertas Karya J.S. Khairen. Penggunaan diksi sangat sering digunakan saat membuat atau menulis sebuah karya sastra seperti puisi, novel, cerpen, cerita rakyat, prosa dan drama.

Didalam Novel Kami Bukan Sarjana Kertas sangat banyak terdapat penggunaan diksi atau gaya bahasa yang sangat menarik untuk di baca dan cocok untuk di analisis tetapi didalam penelitian ini bukan hanya membahas tentang diksi saja namun juga membahas tentang majas yang terdapat dalam novel Kami Bukan Sarjana Kertas. Maka dari itu, penelitian ini sangat penting untuk kami teliti dan dapat memberikan pemahaman kepada pembaca untuk memahami diksi dan majas yang bagus didalam novel Kami Bukan Sarjana Kertas. Selain diksi dan majas penelitian ini kami juga akan membahas tentang makna yang terdapat di dalam novel serta implementasinya sebagai bahan ajar sastra. Penelitian ini juga akan menyatukan stilistika dan implementasi diksi dan majas sebagai bahan ajar sastra di Sekolah Menengah Pertama.

Karya sastra adalah sebuah ciptaan yang di sampaikan secara komunikatif dengan maksud penulis untuk menyampaikan tujuan estetika sebuah karya sastra tersebut. Karya-karya yang sering dibuat ialah untuk menceritakan suatu kisah yang terdapat di dalam sudut pandang orang ketiga maupun yang terdapat didalam orang pertama, dengan menggunakan plot dan melalui berbagai penggunaan perangkat sastra yang memang terkait juga dengan waktu mereka.. Didalam kehidupan kita sehari-hari tidak akan pernah hilang dengan adanya suatu bahasa baik itu secara lisan maupun tulisan. Dalam bahasa Indonesia ada terdapat tiga bagian besar yaitu penggunaa ejaan, diksi, penyusunan kalimat. Didalam penelitian ini yang akan dibahas yaitu penggunaan diksi dan gaya bahasa yang terdapat dalam novel Kami Bukan Sarjana Kertas Karya J.S. Khairen. Penggunaan diksi sangat sering digunakan saat membuat atau menulis sebuah karya sastra seperti puisi, novel, cerpen, cerita rakyat, prosa dan drama.

Didalam Novel Kami Bukan Sarjana Kertas sangat banyak terdapat penggunaan diksi atau gaya bahasa yang sangat menarik untuk di baca dan cocok untuk di analisis tetapi didalam penelitian ini bukan hanya membahas tentang diksi saja namun juga membahas tentang majas yang terdapat dalam novel Kami Bukan Sarjana Kertas. Maka dari itu, penelitian ini sangat penting untuk kami teliti dan dapat memberikan pemahaman kepada pembaca untuk memahami diksi dan majas yang bagus didalam novel Kami Bukan Sarjana Kertas. Selain diksi dan majas penelitian ini kami juga akan membahas tentang makna yang terdapat di dalam novel serta 
implementasinya sebagai bahan ajar sastra. Penelitian ini juga akan menyatukan stilistika dan implementasi diksi dan majas sebagai bahan ajar sastra di Sekolah Menengah Pertama.

Adapun tujuan dari penelitian ini yaitu untukmendeskripsikan jenis Diksi yang terdapat pada Novel Kami Bukan Sarjana Kertas Karya J.S Khairen, mendeskripsikan fungsi Majas yang terdapat pada Novel Kami Bukan Sarjana Kertas Karya J.S Khairen, dan untuk mendeskripsikanpedoman pemelajaran Diksi dan Majas Implementasi dan penyusunan stilistika terhadap pembelajaran pada siswa menengah pertama (SMP).

\section{KAJIAN TEORI}

\section{Stilistika}

Menurut Nurgiyantoro (2014:52-53) stilistika merupakan sebuah cara pengungkapan apa yang ada sidalam batin atau benak kita yang bisa dilakukan oleh seseorang dengan berbagai cara dan hal inilah yang disebut stilistika atau gaya bahasa. Menurut Al'ma'ruf (2012:7) ia menyatakan bahwa stilistika ialah sebuah gaya bahasa yang dapat digunakan oleh seorang pengarang untuk dapat mengungkapkan sebuah fikiran atau ide pokok dalam perasaaan yang akan diungkapkan atau dikemukakan oleh seorang pengarang.

\section{Diksi}

Menurut Keraf, cetakan ke-20 (2010:22) Diksi merupakan suatu pilihan kata atau sangat lebih luas dari apa yang di pantulkan dari hubungan kata-kata itu. Yang di maksd dari istilah ini ialah bukan saja dengan di pergunakan nya untuk menyatakan kata-kata mana yang akan di pakai untuk mengungkapkan suatu idea tau gagasan,tetapi juga akan meliputi yaitu,Rasiologi, gaya bahasa,dan suatu ungkapan. Menurut Widiyamartaya, (2012:45) bahwa diksi atau pilihan kata ialah merupakan kemampuan seseorang dalam membedakan secara benar nuansa- nuasa atau makna yang sesuai dengan gagasan yang ingin di ungkapkan dan kemampuan itu hendak nya disesuaikan dengan situasi atau nilai rasa yang telah dimiliki oleh suatu kelompok masyarakat,pendengar, dan pembaca. 


\section{Majas}

Menurut Goys Keraf, (2012) majas ialah suatu kata bait bila bermakna tiga dasar kejujuran, sopan santun dan menarik.

. Menurut Ratna, (2013 : 181) majas merupakan secara luas meliputi semua kata khiasan penggunaan bahasa yang di anggap lari dari bahasa baku, majas dalam karya sastra secara keseluruhan dianggap sebagai kualitas estetis.

\section{METODE PENELITIAN}

Metode yang digunakan dalam proposal penelitian ini yaitu metode penelitian Kualitatif. Penelitian ini yaitu bersifat deskriptif dan lebih cenderung digunakan untuk menganalisis suatu novel. Menurut Sugiyono (2010:15) Metode deskriptif kuliatatif mendeskriptif kan suatu metode penelitian yang berlandaskan pada paradigma positivisme, dan digunakan meneliti dengan objek alamiah dimana peneliti sebagai kunci dari penelitian tersebut dan pengambilan sumber data yang dilakukan secara sengaja dalam metode ini penelitian juga meneliti sekelompok manusia atau objek dalam sebuah sistem pemikiran ataupun sebuah peristiwa pada masa sekarang. Berdasarkan penelitian di atas pendekatan penelitian yang sangat tepat untuk novel Kami Bukan Sarjana Kertas karya J.S. Khairen adalah metode kualitatif yang bersifat deskriptif.. Dengan alasan, pendekatan kualitatif merupakan penelitian yang mendapatkan data deskriptif ber bentuk kata-kata tertulis.

\section{HASIL PENELITIAN}

Setelah melakukan telaah novel dengan melihat dari landasan teori penelitian ini dilakukan untuk memperoleh data yang berupa diksi yang terdapat pada novel kami bukan sarjana kertas. Dari analisis, berikut merupakan jenis-jenis diksi yang terdapat dalam novel kami bukan sarjana kertas.

\section{Diksi}

1. Kata denotative

Kata denotative dalam novel ini ialah kata kebakaran dan menonton yang terdapat dalam kalimat 
a. Rumah gue kebakaran! Babe! Emak! Adek-adek!. (halaman 71)

b. Barisan manusia yang hanya menonton kebakaran itu, membuat mobil pemadam kebakaran sulit masuk. (halaman 72)

2. Kata konotatif

Kata konotatif dalam novel ini ialah kata ubin masjid dan semburan tawa yang terdapat dalam kalimat

a. Wah buset, adem banget nim cewek Jul! Kayak ubin masjid!. (halaman 27).

Kata ubin masjid disini memiliki makna yang berbeda dengan makna yang sebenarnya. Makna 'ubin masjid' dikalimat ini artinya ialah dingin seperti masjid yang artinya wanita yang dimaksud tersebut sangat enak dipandang dan membuat hati merasa nyaman saat meilhat nya. Ini berarti bahwa kata ubin merupakan kata konotatif.

b. Ogi terbata-bata mengakui nama belakangnya setelah diteror $\mathrm{Bu}$ Lira. Ranjau menahan semburan tawa yang bercampur agak takut kalau-kalau Ogi berulah lagi seperti ketika waktu SMA dulu. (halaman 122)

Kata yang berarti konotatif dalam kalimat ini terdapat pada kata 'semburan'. Kata semburan dalam arti sesungguhnya ialah serangan, yang dimaksud ialah ranjau terpaksa menahan tawa nya karna dia takut kalau Ogi berulah lagi, jadi dia menahan tawa nya agar tidak menimbulkan masalah. Ini berarti bahwa kata semburan merupakan kata konotatif.

3. Kata berasa dalam novel ini ialah kata hambar dan kehilangan yang terdapat dalam kalimat.

a. "Mahasiswa UDEL adalah mahasiswa ujung tebu. Tebu manis bukan? Nah, cobalah gigit ujungnya, hambar. Tidak ada semut yang mau, tidak bisa dioalah jadi gula". (halaman 3). 
Kata 'hambar' sama artinya tidak ada rasa atau dikalimat ini dimaksud artinya mahawasiswa Udel setelah lulus akan dikucilkan dan tidak akan terima di perusahaan mana pun akan selalu menjadi lulusan dari kampus yang tidak berguna. Disini penulis ingin menekankan nilai rasa, sehingga penulis lebih memilih untuk menggunakan kata 'hambar'.

b. "Ditambah lagi sejak ibunya meninggal, Gala seperti kehilangan tempat bersandar dan mengadu, kehilangan tempat berlindung jika ia menolak kehendak ayahnya". (halaman 133).

Kata 'kehilangan' artinya ditinggalkan oleh seseorang yang ada dikehidupan kita. Yang dimaksud dikalimat ini ialah Gala ditinggalkan oleh ibunya yang selalu menjaga dan merawatnya sehingga dia tidak memiliki tempat bersandar lagi seperti dulu nya saat ibunya masih ada. Disini penulis memilih menggunakan kata 'kehilangan' dan lebih menekankan kepada perasaan.

\section{Kata serapan asing}

Kata serapan yang terdapat dalam novel ini ialah kata anyway dan why yang terdapat pada kalimat. Contoh bentuk serapan asing yang terdapat dalam novel ini adalah:

a. Anyway guys, gimana kalau bikin videonya di apartemen Gala aja? Usul ranjau. (halaman 182).

'Anyway' merupakan kata serapan dari bahasa inggris yang artinya bagaimana. Kata ini yaitu bermakna mengusulkan atau mengajak.

b. Why? (halaman 182)

'Why' merupakan kata serapan dari bahasa inggris yang artinya kenapa. Kata ini yaitu bermakna menanyakan sesuatu kepada lawan bicara.

5. Kata konkret

Kata konkret yang terdapat dalam novel ini ialah kata dompet dan ponsel yang terdapat pada kalimat 
a. Saat itu, tidak ada yang percaya, tidak ada yang mau bantu, bahkan orang tua ayah juga sudah pasrah, kalau mau pergi, pergilah. Bawa dompet ini.

b. Tiba-tiba ponsel Juwisa bergetar. Ada sebuah pesan dari nomor tak dikenal

Kata-kata 'dompet', 'ponsel' merupakan kata konkret. Hal ini dikarenekan ketiganya merupakan objek yang dapat diketahui dengan jelas dengan menggunakan indra manusia.

6. Kata umum dan khusus

Kata umum yang terdapat dalam novel ini ialah kata melirik dan menatap yang terdapat pada kalimat. Contoh kata umum ialah seperti kata melihat, karena kata melihat masih dapat dijabarkan menjadi kata melirik, menatap. Dalam novel ini dari pada menggunakan kata umum, penulis lebih mengutamakan penggunaan kata khusus yang lebih menjelaskan tentang keadaan karakter tokoh secara detail, seperti yang terdapat pada kalimat berikut:

a. Sania melirik Arko yang sudah botak, dan Ogi yang juga botak. (halaman 31)

b. Randi menatap ponsel barunya. (halaman 143).

7. Ungkapan standar

Kata uangkapan yang dimaksud disini mengandung makna yang bersifat kiasan, kata ungkapan standar yang terdapat dalam novel ini ialah kata ulat yang busuk dan kири-kири

a. Sekarang kamu mungkin seperti ulat yamg busuk Ogi. Namun jika kamu sabar dan serius, akan datang waktu kamu menjadi kupu-kupu yang indah. (halaman 63).

Kata 'ulat yang busuk' berarti orang yang berada dibawah (kesusahan)

b. Kita mungkin tidak ada yang bisa jadi manusia sempurna dan indah seperti kupu-kupu. Tapi, kita semua diberikan kemampuan untuk bertahan. Jangan mau kalah sama kecoa. Sekarang semua keputusan ada ditangan kamu. (halaman 64) 
Kata 'kupu-kupu' berarti orang yang sedang berada diatas atau diartikan orang yang sukses dalam karier.

8. Kata abstrak

Kata abstrak yang terdapat dalam novel ini ialah kata mencairkan dan terpisahkan yang terdapat pada kalimat

a. Sepasang manusia, berjalan didunia mencairkan tanda, pada perasaan. (halaman 118)

b. Sepasang manusia, menyimpan cerita terpisahkan jarak, tak ada cerita. (halaman 118)

Kata 'mencairkan' dan 'terpisahkan' merupakan kata-kata yang mengarah pada gagasan. Maka, dapat dinyatakan bahwa kedua kata ini merupakan kata abstrak .

9. Kata vulgar

Kata vulgar yang terdapat dalam novel ini ialah kata otak bokep yang terdapat pada kalimat. Kata ini sering digunakan anak remaja dalam setiap kali sedang berbicara atau bercanda kepada sesama teman dekatnya. Seperti yang tercantum pada kalimat:'

a. Oh gosh! Dasar lo otak botak! Otak bokep masih aja dipelihara. (halaman 2)

Kata 'otak bokep' merupakan kata-kata yang mengarah atau ungkapan kepada seseorang yang sedang berpikiran kotor terhadap sesuatu hal.

Di dalam diksi memilki kata pilihan yang menyampaikan gagasan atau cerita di dalam novel yang jarang didengar oleh setiap pembaca dan dapat menambah pengetahuan kata-kata baru yang mungkin jarang didengar oleh pembaca sebelumnya.

Penggunaan kata yang berwujud permajasan mempengaruhi gaya dan keindahan bahasa di dalam karya sastra yang bersangkutan. maka berikut penulis mempaparkan hasil analisis yang telah dilakukan. 


\section{Majas}

2.1 Majas perbandingan

1. Majas Personitifikasi Contoh majas :

a. Rumahnya yang sudah seperti istana itu seketika beku (halaman 131)

b. Ponsel ayah gala berbunyi (halaman 131)

2. Majas Eufemisme

a. Kampus udel sarang narkoba (halaman 275)

b. Puluhan mahasiswa udel serta belasan jajaran rektorter sangkut narkoba (halaman 275)

c. Ribuan ijazah palsu di kampus udel (halaman 275)

3. Majas Hiperbola Contoh majas :

a. Semua terjadi cepat tak ada kisah drama atau sinteron bahkan kisah Box office sekalipun yang cocok menggambarkan situasi aneh hari ini dirumah juwisa Gala adalah satu-satu nya yang akan meneruskan bisnis nanti. (halaman 256)

b. Ayah gala memiliki banyak unit bisnis .mulai dari jasa kredit keungan, usaha tambang batubara, pengolahan sawit hingga pabrik kertas. (halaman 131)

\subsection{Majas pertentangan}

1. Majas litotes Contoh majas :

a. Bagi Ogi kuliah adalah keterpaksaan, suatu kemunduran mental (halaman 02)

b. Di Udel ini ibarat mendaki gunung, lewati lembah, dikejar beruang yang lag PMS, terjun kejurang, kesasar di padang pasir, kecebur di sungai amazon dan dikejar anaconda sebesar pohon kelapa. (halaman 02)

2. Majas Antitesis Contoh majas :

a. Kalian jangnan mau dibodohi harga buku ini tidak sampai seratus ribu, penipu tuh dosen (halaman 14)

b. Kalau bukan kita yang mengubah nasib keluarga, siapalagi (halaman14) 
2.3 Majas sindirian

1. Majas ironi Contoh majas:

a. Jadilah anak yang mandragua sesuai nama mu! (halaman 124)

b. Semoga ogi menjaadi anak yang sukses (halaman 21)

2. Majas Sinisme contoh majas

a. Nah, tuh! gak beli asli ogi menyindir ranjau yang dulu pernah beli foolwers (halaman 16)

b. Apaan sih nih si om gigolo mesum mulu otak lo ranjau (halaman 17)

\subsection{Majas penegasan}

1. Majas Repetisi contoh majas

a. Ogi ingin menjadi lebih baik, saya ingin membanggakan orang tua, saya ingin membuat mereka bahagia. (halaman 42)

b. Kami wisudawan-wisudawati UDEL, berjanji akan berkontribusi dengan sepenuh jiwa dan raga, dengan sekuat tenanga untuk lingkungan dan kemaslahatan Negara (halaman 334)

Fungsi majas dalam novel ini ialah untuk menarik pembaca dan menciptakan rasa keinginan membaca dalam novel karena banyak kata-kata yang sangat menarik dan menimbulkan keinginan untuk membaca.

\subsection{Tinjauan stilistika dan implementasi sebagai bahan ajar pada sekolah menengah pertama.}

Sesuai dengan tingkat pembelajaran siswa sekolah menengah pertama, siswa harus bisa menikmati atau menyajikan karya sastra sebagai tingkat pembelajaran mereka agar dapat menjadikan karya sastra sebagai pembalajaran yang dapat mereka pahami, analisis dan nikmati. 
Didalam sebuah karya sastra seperti novel terdapat diksi dan majas yang dimana siswa sekolah menengah pertama harus memahami bagaimana caranya untuk menganalisis diksi dan majas tersebut. Manfaat diksi didalam Novel Kami Bukan Sarjana Kertas yaitu didalam diksi memilki kata pilihan yang menyampaikan gagasan atau cerita didalam novel yang jarang didengar oleh setiap pembaca dan dapat menambah pengetahuan kata-kata baru yang mungkin jarang didengar oleh pembaca sedangkan fungsi majas dalam novel ini ialah untuk menarik pembaca dan menciptakan rasa keinginan membaca dalam novel karena banyak kata-kata yang sangat menarik dan menimbulkan rasa keinginan untuk membaca.

Ada empat fungsi sastra dan tujuan pembelajaran sastra yang dapat diperoleh siswa sekolah menengah pertama melalui membaca analisis novel kami bukan sarjana kertas antara lain:

1) Dapat memotivasi siswa untuk mengekspresikan bahasa

Pembelajaran sastra dapat membuat siswa menjadi cermat dan mampu mempelajari sesuatu relevan yang bermanfaat bagi kehidupan nya sendiri dan juga orang lain. melalui membaca novel kami bukan sarjana kertas maka siswa akan mengatahui atau menemukan berbagai kata-kata kiasan yang mungkin belum pernah didengar atau dibaca sebelumnya yang ada didalam novel tersebut dan memberikan pengetahuan baru kepada siswa setelah membaca karya sastra.

2) Alat untuk mendorong siswa untuk memperoleh bahasa

Mempelajari sastra dapat secara tidak langsung dapat membantu kita atau siswa dalam belajar bahasa. Makna yang terdapat didalam sebuah sastra belum tentu dapat dimengerti begitu saja kalau siswa tersebut tidak menguasai bahasa. Sastra dapat membantu siswa dalam meningkatkan pemerolehan bahasa, menambah kemampuan berbahasa dan dapat melaksanakan proses pembelajaran bahasa yang dapat membuat siswa senang. Bahasa yang dipakai didalam novel kami bukan sarjana kertas sangat lah berbeda dengan yang lain, bahasa nya sederhana tetapi penuh dengan makna yang sangat dalam dan sangat mudah dipahami oleh siswa sekolah menengah pertama.

3) Alat untuk mengembangkan kemampuan berpendapat

Sastra yaitu alat yang bagus untuk mengembangkan kemampuan siswa untuk memahami suatu makna gaya bahasa dan membuat suatu pendapat dalam sebuah karya 
sastra. Dengan demikian melalaui sastra, siswa mendapatkan kesempatan untuk mengemukakan pendapat sendiri melalui teks sastra tersebut.

4) Sarana untuk mendidik siswa

Pembelajaran sastra dapat membantu siswa untuk berimajinasi dalam menggunakan kata-kata atau yang disebut diksi. Melalui analisis novel ini siswa diharapkan dapat membuat suatu karya sastra yang lebih indah dan bagus lagi dengan menggunakan kata-kata yang sangat menarik dan penuh dengan makna. Dengan menggunakan kata-kata yang imajinasi nya tinggi dapat membuat siswa menguasai atau mengerti kata-kata yang sulit yang jarang didengar menjadi dapat dipahami oleh siswa karna telah membaca sebuah karya sastra yang sangat menarik

\section{KESIMPULAN}

Berdasarkan dari hasil pembahasan novel kami bukan sarjana kertas karya J.S Khairen maka dengan ini penulis menarik hasil kesimpulan bahwa melalui tokoh ogi dalam novel ini menggambarkan sebuah kehidupan tokoh yang sangat banyak mengalami rintangan dan bahkan menyedihkan, dimana tokoh utama ogi sangat putus asa dalam menjalankan kehidupan. Tapi dia memiliki teman-teman yang mendukung baik secara materi dan non materi. Cerita ini memberikan inspirasi bagi siswa sekolah menegah pertama ataupun kita sebagai pembaca agar bekerja keras dan penuh semangat. Karena dalam sebuah kegagalan akan menjadi buah kesuksesan bagi kita yang selalu ingin mencapai kesuksesan. Penggunaan diksi dan majas dalam novel memiliki kata-kata yang sangat jarang kita dengar sehingga setiap yang membaca novel ini bisa mendapatkan ilmu baru dan pengetahuan baru.

\section{SARAN}

1. Untuk penulis novel ini melihat kelebihan dari isi novel tersebut sangatlah bermutu bagi setiap pembaca yang belum banyak mengatahui tentang kata-kata khiasan yang terdapat dalam novel tersebut sehingga dapat menambah wawasan dan pengetahuan bagi setiap yang membaca novel tersebut dan adapula kekurangan didalam novel ini yang terlalu banyak mengandung kata vulgar yang sebenarnya tidak layak dibaca oleh siswa sekolah menengah pertama. 
2. Bagi siswa sekolah menengah pertama dapat lebih giat lagi dalam mencapai keinginan nya dan dapat mengetahui banyak hal tentang bahasa khiasan yang sangat jarang kita dengarkan didalam kehidupan sehari-hari kita dan dapat pula menikmati bahasa khiasan yang terdapat pada novel kami bukan sarjana kerta karya J.S Khairen.

3. Bagi universitas novel ini sangtatlah bagus untuk dibaca oleh mahasiswa dimana novel ini memangla menceritakan tentang kehidupan berbagai mahasiswa dan mungkin salah satu mahasiswa di universitas pernah merasakan nya dan novel ini juga banyak akan membantu mahasiswa dalam menemukan banyak kata-kata kiasan yang mungkin tidak pernah didengar sebelumnya oleh mahasiswa.

\section{DAFTAR PUSTAKA}

Abimuda, 2015. Pengertian majas, macam-macam majas, dan contoh majas lengkap. http://www.abimuda.com/2015/09/pengertian-dan-macam-macam-majaslengkap-besertacontoh.html. diakses pada tanggal 16 april 2016.

Ah-ma'ruf, Ali Imran. 2012. Stilistika (teori, metode, dan aplikasi pengkajian estetika bahasa). Surakarta: cakra books.

Akbar, S.,Retno, W. \& Andayani. 2013. kajian sosiologi sastra dan nilai pendidikan dalam novel tuan guru karya Salman Faris, Jurnal Pendidikan Bahasa dan Sastra, 1 (1), 5468.https://eprints.uns.ac.id/2406/

Akbar, Sa'dun. 2015. Instrumen perangkat pembelajaran. Bandung: PT.remaja rosda karya.

Chaplin, J.P. 2011. Kamus lengkap psikologi. Diterjemahkan: kartini kartono. Jakarta: PT.Radja grafindo persada.

Endre, Fahrudin. 2012. Dasar-dasar keterampilan menulis. Jakarta: kanisius.

Keraf, Groys. 2010. Diksi dan gaya bahasa, Jakarta: PT Gramedia pustaka utama.

Ratna, Myoman Kutha. 2013. Stilistika kajian puitika bahasa, sastra, dan budaya. Yogyakarta: pustaka pelajar.

Sugiono. 2010. Metode penelitian pendidikan pendekatan kuantitatif, kualitatif dan R\&D. Bandung: alfabeta. 
Sugiono. 2015. Metode penelitian kombinasi (mix methods). bandung: alfabeta.

Satoto. 2012. Stilistika. Yogyakarta: ambak.

Tarigan, Henri Guntur. 2013. Pengajaran gaya bahasa. Bandung: angkasa. 